\title{
RAB5C wt Allele
}

National Cancer Institute

\section{Source}

National Cancer Institute. RAB5C wt Allele. NCI Thesaurus. Code C104815.

Human RAB5C wild-type allele is located in the vicinity of $17 \mathrm{q} 21.2$ and is approximately 30

$\mathrm{kb}$ in length. This allele, which encodes Ras-related protein Rab-5C, is involved in GTP

metabolism and may be involved in vesicle transport. 